Acta Agroph., 2018, 25(4), 409-419

doi: $10.31545 /$ aagr/99081

\title{
SENSITIVITY OF 24 SUGAR BEET CULTIVARS TO WATER DEFICIT DURING EMERGENCE
}

\author{
Pawet Skonieczek ${ }^{1}$, Mirosław Nowakowski ${ }^{1}$, Jacek Piszczek ${ }^{2}$, \\ Lukasz Matyka ${ }^{1}$, Marcin Żurek ${ }^{1}$, Bogumił Rychcik ${ }^{3}$, Milena Kaźmierczak ${ }^{3}$ \\ ${ }^{1}$ Department of Root Crops Production Technology, Plant Breeding and Acclimatization Institute - \\ National Research Institute, Powstańców Wielkopolskich 10, 85-090 Bydgoszcz, Poland \\ ${ }^{2}$ Regional Experimental Station Torun, Institute of Plant Protection - National Research Institute \\ Pigwowa 16 St., 87-100 Torun, Poland \\ ${ }^{3}$ Department of Agroecosystems, University of Warmia and Mazury in Olsztyn \\ Plac Łódzki 3, 10-718 Olsztyn, Poland \\ e-mail: pawelsko@wp.pl
}

\begin{abstract}
The aim of this study was to evaluate, in 3 experiments, seedling emergence and sensitivity to temporary soil water deficit in 24 sugar beet cultivars. Seeds were sown in 2012 and 2013 in containers $(60 \times 40 \times 15 \mathrm{~cm})$ filled with a soil classified as Luvisol (with $65 \%$ field water capacity) and placed in an phytotron. For 2 weeks, until the first counting of seedlings, the temperature was maintained at $10^{\circ} \mathrm{C}$, and then it was raised to $15^{\circ} \mathrm{C}$ to simulate the temperature increase occurring in the spring period in the field. At the first stage of the study, the number of emerged seedlings was counted 14 and 21 days after sowing. After the following 2 weeks, in the second pair of leaves unfolded stage, the plants were not watered for 6 days to evaluate on day 7 their sensitivity to soil moisture deficit. The above cycle was repeated, and the plants were not supplied with water over a period of 6 successive days. At the end of that period, the seedlings were counted, and the ratio of surviving seedlings to the number of seedlings before the first water deficit was calculated again. Under controlled conditions, high emergence capacity (14 days after sowing) was noted in cv. Janosik, Julietta, and Silvetta, whereas very high final emergence capacity (21 days after sowing) was observed in cv. Agent and Julietta. Sugar beet cv. Huzar, Lukas, and Expert were the least sensitive to soil moisture deficit and they can, therefore, be recommended for cultivation in areas prone to water deficit at the beginning of the growth season. Among the conventional cultivars of sugar beet, there are also cultivars with a low susceptibility to drought that increasingly more often causes problems in regions of intensive production of root crops.
\end{abstract}

Keyw ords: Beta vulgaris, emergence capacity, seedling survival, simulated drought 


\section{INTRODUCTION}

Water and dissolved nutrients are responsible for the basic physiological processes in plants. The storage root yield and sugar content of sugar beets are determined by the genetic potential of a cultivar, soil and climate conditions, and the number and distribution of plants on a plantation (Sadeghian et al. 2000). The optimal density of 90,000-100,000 plants per hectare requires high field emergence capacity after sowing (Piszczek et al. 2012). Drought poses a serious threat for sugar beets, in particular, the younger plants (Kenter et al. 2006).

In many European countries, especially in Poland, low precipitation in spring and uneven distribution of rainfall during the growing season contribute to soil moisture deficit which has a corresponding negative effect on sugar beet emergence, final plant density and yields (Pidgeon et al. 2006, Nowakowski 2013). Water deficit can significantly decrease emergence capacity in field conditions, and thus reduce final plant density (Abdollahian-Noghabi and Froud-Williams 1998).

The factor limiting significantly the emergence of sugar beet and yield can also be low temperatures (Pidgeon et al. 2001). Periodic water deficiency inhibits the development of the leaf apparatus, decreases photosynthetic rate and, consequently, the root and sugar yields (Clover et al. 1999, Bloch 2006). Soil drought and high temperatures can lead to a considerable decrease in the utilisation of soil nutrients. Tolerance to water deficit is associated with the synthesis of proline, betaine, dehydrin, and osmotin in plants (Gzik 1996, Kevrešan et al. 1998, Wu et al. 2014). These compounds protect cell structures, maintain membrane integrity and prevent protein denaturation. Compounds that protect plants against oxidative stress and metabolic disorders are also synthesised, including carotenoids, glutathione and ascorbic acid. During periods of water deficit, significant differences in catalase and peroxidase activity, chlorophyll fluorescence, and $\mathrm{H}_{2} \mathrm{O}_{2}, \mathrm{Na}$ and $\mathrm{K}$ levels were observed in sugar beet leaves between cultivars (Romano et al. 2013, Wu et al. 2014).

Tuğrul et al. (2012) demonstrated that sugar beets have a high demand for water during seed germination and seedling development and that their daily water requirements range from 290 to 5001 per $1 \mathrm{~kg}$ of plant dry matter. Hills et al. (1990) reported that water stress at the beginning of the growth season considerably decreases the root yield of sugar beets and, according to Brown et al. (1987), this stressor reduces sugar content. However, Winter (1980) and Dunham (1988) argued that drought does not significantly influence sucrose accumulation. According to Kryszan (1986) as well as Skonieczek and Koc (2011), the water-holding capacity of soil plays an important role in satisfying the water needs of various plants, including root crops.

The objective of this study was to evaluate emergence and seedling sensitivity to temporary soil water deficit in 24 sugar beet cultivars during initial stages of plant growth. 


\section{MATERIALS AND METHODS}

Seedling emergence and the sensitivity of sugar beet cultivars to periodic water deficit was investigated in 2012 and 2013 at the laboratory of the Department of Root Crops Production Technology Bydgoszcz of the Plant Breeding and Acclimatisation Institute - National Research Institute, in cooperation with the Department of Agroecosystems of the University of Warmia and Mazury in Olsztyn and with the Institute of Plant Protection - National Research Institute in Torun (Poland). The research method described below was used to conduct two experiments (D1 and D2) in 2012 and one experiment (D3) in 2013. The study was performed on sugar beet cultivars characterised by different sugar content (types: $\mathrm{N}$ - normal, NS - normal/sugar, S - sugar): Agent (NS; SESvanderHave), Balladyna (N; WHBC), Britannia (NS; KWS), Casino (N; Maribo), Delano (NS; Maribo), Expert (S; SESvanderHave), Goldena (N; KWS), Huzar (N; WHBC), Imperial (N; Maribo), Jagoda (N; KHBC), Jagusia (N; KHBC), Janosik (N; KHBC), Janowa (NS; KHBC), Jonas (NS; Strube), Julietta (N; KWS), Lukas (S; Strube), Monza (N; Syngenta), Nancy (N; Maribo), Nevenka (NS; KWS), Pasja (NS; SESvanderHave), Pewniak (N; SESvanderHave), Schubert (NS; Strube), Silvetta (N; Syngenta) and Sokrates (NS; Strube). The tested cultivars are diploid (except Balladyna which is triploid) and rhizomania-tolerant, cv. Expert is also drought-tolerant, and cv. Julietta is Heterodera schachtii-tolerant. The plants were sown in three replicates of 50 pelleted seeds each, in containers $(60 \times 40 \times 15 \mathrm{~cm})$ filled with a soil classified as Luvisol (sandy loam; $54-58 \%$ sand, $19-22 \%$ silt and $22-24 \%$ clay; the soil composition was determined based on the Bouyoucos-Casagrande method). One container represented one replicate. The soil was obtained from a sugar beet field in Minikowo (Region of Kujawy and Pomorze). The agrochemical analysis revealed that the soil was characterised by moderate levels of phosphorus (colorimetric method) and nitrate nitrogen (ionoselctive electrode), low content of potassium, magnesium and calcium (AAS method), slightly acidic $\mathrm{pH}$ and low humus content (Tiurin method) (Tab. 1).

The field water capacity of the soil had been determined before the containers were filled with soil. Each container was filled with $25 \mathrm{~kg}$ of soil and $1560 \mathrm{ml}$ of water was added to bring the actual soil moisture to the optimal level of $65 \%$ water capacity, which was then maintained by watering until the second count of seedlings.

After sowing, the containers were placed in a phytotron. The temperature was maintained at $10^{\circ} \mathrm{C}$ for 2 weeks until the first seedling count, and increased to $15^{\circ} \mathrm{C}$ during seedling growth. The temperature increase was aimed at promoting the occurrence of water deficiency symptoms in the second stage of tests with simulated drought and meeting the conditions during plant emergence in the field. Seedlings were exposed to artificial lighting from Fluora lamps for 12 hours daily. The number 
of emerged seedlings was counted 14 days (cotyledon stage; $\mathrm{BBCH} 10$ ) and 21 days (first pair of leaves unfolded stage; $\mathrm{BBCH} 12$ ) after sowing. Two weeks after the second seedling count, the plants were not watered for further 6 days. On day 7, the number of seedlings (second pair of leaves unfolded stage; BBCH 14) that survived the simulated drought was counted and $1100 \mathrm{ml}$ water was added to each container to bring soil moisture to $65 \%$ of field water capacity. On the following 2 days, plants were supplied with $550 \mathrm{ml}$ of water per container to maintain soil moisture levels. The above cycle was repeated, and plants were not supplied with water over a period of 6 successive days (soil moisture was determined at approximately $35 \%$ of field water capacity on day 6). At the end of that period, seedlings were counted again, and the ratio of surviving seedling to the number of seedlings before the first water deficit was calculated.

Table 1. Characteristics of the soil used in experiments D1, D2 and D3 (2012-2013)

\begin{tabular}{lccccccc}
\hline \multirow{2}{*}{$\begin{array}{c}\text { Experiment } \\
\text { (Year) }\end{array}$} & \multirow{2}{*}{$\mathrm{pH}_{\mathrm{KCl}}$} & \multicolumn{5}{c}{ Content $\left(\mathrm{mg} \mathrm{dm}^{-3}\right)$} & Humus content \\
\cline { 3 - 6 } & ${\mathrm{N}-\mathrm{NO}_{3}}$ & $\mathrm{P}$ & $\mathrm{K}$ & $\mathrm{Mg}$ & $\mathrm{Ca}$ & $(\%)$ \\
\hline D1 (2012) & 6,3 & $25 \mathrm{~m}$ & $47 \mathrm{~m}$ & 751 & $21 \mathrm{vl}$ & $460 \mathrm{vl}$ & 1,861 \\
$\mathrm{D} 2(2012)$ & 6,4 & $23 \mathrm{~m}$ & $49 \mathrm{~m}$ & 901 & $25 \mathrm{vl}$ & $485 \mathrm{vl}$ & 1,751 \\
D3 (2013) & 6,4 & $26 \mathrm{~m}$ & $47 \mathrm{~m}$ & 961 & $24 \mathrm{vl}$ & $490 \mathrm{vl}$ & 1,791 \\
\hline
\end{tabular}

Content class: vl - very low, 1 - low, $\mathrm{m}$ - medium

In the control treatment, sugar beet plants of the analysed cultivars were grown under optimal conditions with $65 \%$ of field water capacity through the entire experiment and temperatures of 10 and $15^{\circ} \mathrm{C}$, respectively.

The results were processed statistically by analysis of variance using oneway ANOVA (STATISTICA ${ }^{\circledR}$ 9.0), and differences between mean values were determined by Tukey's test at significance level $p=0.05$. Additionally, standard deviation (SD) was calculated for the analysed parameters of sugar beet plants, including 9 replicates from 3 experiments.

\section{RESULTS AND DISCUSSION}

Seedling emergence values were similar in all three experiments (Tabs 2 and 3). Significant differences in seedling emergence were observed between sugar beet cultivars on both count dates in all experiments.

An analysis of the mean values noted in three experiments, 14 days after sowing (Tab. 2), revealed high emergence capacity (above 93\%) in cv. Janosik (94.8\%), Julietta (94.1\%), and Silvetta (93.9\%).

Twenty-one days after sowing (Tab. 3), very high emergence capacity (above 96\%) was evident in cv. Agent (97.7\%), Julietta (97.6\%), Sokrates (96.2\%), Lukas (96.1\%), and Expert (96.0\%). According to Sadeghian and Khodaii (1998), the 
emergence capacity of beet seeds is largely determined by the combining ability of breeding lines and additive genetic effects (Gunasekera and Berkowitz 1993) together with rigorous seed selection.

Table 2. Emergence of selected sugar beet cultivars after 14 days in 3 experiments (D1, D2 and D3)

\begin{tabular}{|c|c|c|c|c|c|}
\hline \multirow{3}{*}{ Sugar beet cultivar } & \multicolumn{5}{|c|}{ Emergence (\%) } \\
\hline & \multicolumn{3}{|c|}{ Mean } & Mean & $\mathrm{SD}$ \\
\hline & D1 & D2 & D3 & \multicolumn{2}{|c|}{ for D1, D2 and D3 } \\
\hline Agent & $92.6^{\text {abcde }}$ & $82.8^{\text {cde }}$ & $89.4^{\mathrm{fgh}}$ & $88.3^{\mathrm{abcd}}$ & 4.9 \\
\hline Balladyna & $76.0^{\mathrm{jk}}$ & $73.0^{\text {hij }}$ & $81.8^{\mathrm{k}}$ & $76.9^{\text {efg }}$ & 7.2 \\
\hline Britannia & $66.0^{1}$ & $62.7^{1}$ & $70.1^{1}$ & $66.3^{\mathrm{h}}$ & 3.8 \\
\hline Casino & $87.2^{\text {efgh }}$ & $82.2^{\text {cdef }}$ & $91.8^{\mathrm{def}}$ & $87.1^{\text {abcd }}$ & 6.1 \\
\hline Delano & $85.3^{\text {fghi }}$ & $76.3^{\mathrm{ghi}}$ & $80.7^{\mathrm{k}}$ & $80.8^{\text {def }}$ & 4.1 \\
\hline Expert & $96.2^{\mathrm{a}}$ & $83.0^{\text {cde }}$ & $84.8^{\mathrm{ijk}}$ & $88.0^{\mathrm{abcd}}$ & 7.2 \\
\hline Goldena & $82.6^{\text {ghij }}$ & $78.6^{\mathrm{efg}}$ & $89.4^{\text {fgh }}$ & $83.5^{\text {bcde }}$ & 5.3 \\
\hline Huzar & $90.1^{\mathrm{ab}}$ & $84.6^{\text {bcd }}$ & $89.9^{\text {fgh }}$ & $88.2^{\mathrm{abcd}}$ & 5.2 \\
\hline Imperial & $93.3^{\mathrm{abcd}}$ & $85.1^{\text {bcd }}$ & $92.7^{\text {cdef }}$ & $90.4^{\mathrm{abc}}$ & 5.4 \\
\hline Jagoda & $87.2^{\text {defg }}$ & $80.2^{\text {def }}$ & $86.3^{\text {hij }}$ & $84.6^{\text {bcde }}$ & 4.7 \\
\hline Jagusia & $91.8^{\text {abcde }}$ & $85.7^{\mathrm{abc}}$ & $93.2^{\text {bcde }}$ & $90.2^{\mathrm{abc}}$ & 3.9 \\
\hline Janosik & $95.4^{\mathrm{ab}}$ & $90.4^{\mathrm{a}}$ & $98.6^{\mathrm{a}}$ & $94.8^{\mathrm{a}}$ & 3.7 \\
\hline Janowa & $72.7^{\mathrm{k}}$ & $71.6^{\mathrm{ij}}$ & $82.3^{\mathrm{ijk}}$ & $75.5^{\mathrm{efg}}$ & 5.7 \\
\hline Jonas & $89.3^{\text {cdef }}$ & $77.4^{\text {fgh }}$ & $80.2^{\mathrm{k}}$ & $82.3^{\text {cdef }}$ & 5.6 \\
\hline Julietta & $95.7^{\mathrm{a}}$ & $89.3^{\mathrm{ab}}$ & $97.3^{\mathrm{abc}}$ & $94.1^{\mathrm{a}}$ & 3.9 \\
\hline Lukas & $88.8^{\text {bcde }}$ & $82.3^{\text {cde }}$ & $87.6^{\text {ghi }}$ & $86.2^{\text {abcd }}$ & 4.7 \\
\hline Monza & $80.4^{\mathrm{ij}}$ & $79.2^{\mathrm{efg}}$ & $91.1^{\mathrm{efg}}$ & $83.6^{\text {bcde }}$ & 5.8 \\
\hline Nancy & $94.7^{\mathrm{abc}}$ & $86.3^{\mathrm{abc}}$ & $95.3^{\mathrm{abcd}}$ & $92.1^{\mathrm{ab}}$ & 4.7 \\
\hline Nevenka & $92.1^{\text {abcde }}$ & $86.8^{\mathrm{abc}}$ & $95.9^{\text {abcd }}$ & $91.6^{\mathrm{ab}}$ & 4.5 \\
\hline Pasja & $87.3^{\text {defg }}$ & $71.6^{\mathrm{ij}}$ & $67.2^{1}$ & $75.4^{\text {efg }}$ & 10.2 \\
\hline Pewniak & $81.1^{\text {hij }}$ & $70.3^{\mathrm{jk}}$ & $70.4^{1}$ & $73.9^{\text {fgh }}$ & 6.0 \\
\hline Schubert & $81.7^{\text {ghij }}$ & $66.2^{\mathrm{kl}}$ & $61.3^{\mathrm{m}}$ & $69.7^{\text {gh }}$ & 9.6 \\
\hline Silvetta & $95.2^{\mathrm{ab}}$ & $89.3^{\mathrm{ab}}$ & $97.1^{\mathrm{abc}}$ & $93.9^{\mathrm{a}}$ & 4.2 \\
\hline Sokrates & $95.4^{\mathrm{ab}}$ & $85.8^{\mathrm{abc}}$ & $89.6^{\text {fgh }}$ & $90.3^{\mathrm{abc}}$ & 4.8 \\
\hline
\end{tabular}

D1, D2 and D3 - calculated for 9 replicates; SD - standard deviation; means within the same column followed by the same letter are not significantly different

According to Michalska-Klimczak and Wyszyński (2010), optimal seedling emergence in sugar beets requires precipitation levels of 25-40 $\mathrm{mm}$ in April and 46-75 $\mathrm{mm}$ in May, subject to soil type. Between initial emergence and the formation of the crop stand, soil moisture should be maintained at $60-70 \%$ of field water capacity (Allen et al. 1998). The development of sugar beet seedlings and plants is visibly impaired when field water capacity is reduced to $40 \%$ during soil drought (Pidgeon et al. 2001). The impairment can be attributed to the limited availability and utilisation of nutrients, reduced biological activity and productivity of soil (Nowakowski 2013), as well as inhibition of the basic physiological and biochemical processes of plants, which depend upon water supply (Kevrešan et al. 1998).

The results of the experiment revealed that soil moisture deficit inhibited seedling development to a different extent in the investigated group of sugar beet cultivars. The percentage of beet seedlings that survived the first and second water deficit was more differentiated between the three experiments (Tabs 4 and 5) than 
emergence capacity determined in each experiment. This may result from an insufficient uniformity of the seed material which came from different commercial batches of seven breeding companies.

Table 3. Emergence of selected sugar beet cultivars after 21 days in 3 experiments (D1, D2 and D3)

\begin{tabular}{|c|c|c|c|c|c|}
\hline \multirow{3}{*}{ Sugar beet cultivar } & \multicolumn{5}{|c|}{ Emergence (\%) } \\
\hline & \multicolumn{3}{|c|}{ Mean } & Mean & SD \\
\hline & D1 & D2 & D3 & \multicolumn{2}{|c|}{ for D1, D2 and D3 } \\
\hline$\overline{\text { Agent }}$ & $99.8^{\mathrm{a}}$ & $93.2^{\mathrm{ab}}$ & $100.0^{\mathrm{a}}$ & $97.7^{\mathrm{a}}$ & 3.4 \\
\hline Balladyna & $94.4^{\mathrm{fg}}$ & $86.0^{\text {hij }}$ & $94.1^{\text {fgh }}$ & $91.5^{\mathrm{ef}}$ & 4.3 \\
\hline Britannia & $94.2^{\text {fg }}$ & $86.3^{\text {ghij }}$ & $92.8^{\mathrm{ghi}}$ & $91.1^{\text {ef }}$ & 4.0 \\
\hline Casino & $96.5^{\text {bcde }}$ & $88.1^{\text {efghij }}$ & $94.0^{\text {fgh }}$ & $92.9^{\text {bcde }}$ & 4.0 \\
\hline Delano & $94.8^{\mathrm{fg}}$ & $87.0^{\text {ghij }}$ & $95.2^{\text {ef }}$ & $92.3^{\text {cdef }}$ & 4.1 \\
\hline Expert & $98.1^{\mathrm{abcd}}$ & $91.3^{\mathrm{abcd}}$ & $98.6^{\mathrm{ab}}$ & $96.0^{\mathrm{abc}}$ & 3.7 \\
\hline Goldena & $96.4^{\text {bcde }}$ & $90.2^{\text {bcde }}$ & $97.6^{\mathrm{bc}}$ & $94.7^{\text {abcde }}$ & 3.9 \\
\hline Huzar & $93.4^{\mathrm{g}}$ & $87.1^{\text {fghij }}$ & $90.1^{\mathrm{jk}}$ & $90.2^{\mathrm{f}}$ & 3.2 \\
\hline Imperial & $97.6^{\text {abcde }}$ & $89.3^{\text {cdefg }}$ & $97.4^{\mathrm{bcd}}$ & $94.8^{\mathrm{abcd}}$ & 4.3 \\
\hline Jagoda & $96.2^{\text {bcdef }}$ & $84.8^{j}$ & $89.3^{\mathrm{k}}$ & $90.1^{\mathrm{f}}$ & 5.3 \\
\hline Jagusia & $96.6^{\text {bcdef }}$ & $88.6^{\text {defgh }}$ & $95.4^{\mathrm{def}}$ & $93.5^{\text {bcdef }}$ & 4.0 \\
\hline Janosik & $98.6^{\mathrm{ab}}$ & $91.2^{\mathrm{abcd}}$ & $94.4^{\text {efg }}$ & $94.7^{\text {abcd }}$ & 3.3 \\
\hline Janowa & $95.1^{\mathrm{efg}}$ & $85.9^{\text {hij }}$ & $90.9^{\mathrm{ijk}}$ & $90.6^{\mathrm{f}}$ & 4.2 \\
\hline Jonas & $93.3^{\mathrm{g}}$ & $88.0^{\text {efghi }}$ & $95.2^{\text {de }}$ & $92.2^{\text {cdef }}$ & 3.6 \\
\hline Julietta & $99.1^{\mathrm{ab}}$ & $93.6^{\mathrm{a}}$ & $100.0^{\mathrm{a}}$ & $97.6^{\mathrm{a}}$ & 3.0 \\
\hline Lukas & $98.7^{\mathrm{ab}}$ & $91.2^{\mathrm{abcd}}$ & $98.3^{\mathrm{abc}}$ & $96.1^{\mathrm{ab}}$ & 3.8 \\
\hline Monza & $93.4^{\mathrm{g}}$ & $85.3^{\mathrm{ij}}$ & $92.1^{\mathrm{hij}}$ & $90.3^{f}$ & 4.0 \\
\hline Nancy & $98.1^{\mathrm{abcd}}$ & $90.3^{\text {bcdef }}$ & $97.9^{\mathrm{bc}}$ & $95.4^{\mathrm{abcd}}$ & 3.9 \\
\hline Nevenka & $95.7^{\text {cdefg }}$ & $89.0^{\text {defgh }}$ & $96.3^{\text {cde }}$ & $93.7^{\text {bcdef }}$ & 3.9 \\
\hline Pasja & $95.4^{\text {defg }}$ & $87.1^{\text {ghij }}$ & $94.1^{\text {fgh }}$ & $92.2^{\mathrm{def}}$ & 4.3 \\
\hline Pewniak & $98.7^{\mathrm{ab}}$ & $90.2^{\text {bcde }}$ & $98.8^{\mathrm{ab}}$ & $95.9^{\text {abcd }}$ & 4.4 \\
\hline Schubert & $87.9^{\mathrm{h}}$ & $86.3^{\text {ghij }}$ & $99.1^{\mathrm{ab}}$ & $91.1^{\text {ef }}$ & 6.1 \\
\hline Silvetta & $98.2^{\mathrm{abc}}$ & $90.5^{\text {abcde }}$ & $97.4^{\mathrm{bcd}}$ & $95.4^{\mathrm{ab}}$ & 3.8 \\
\hline Sokrates & $96.4^{\text {bcdef }}$ & $92.3^{\mathrm{abc}}$ & $100.0^{\mathrm{a}}$ & $96.2^{\mathrm{ab}}$ & 3.8 \\
\hline
\end{tabular}

D1, D2 and D3 - calculated for 9 replicates; SD - standard deviation; means within the same column followed by the same letter are not significantly different

Significant differences in the percentage of live seedlings were observed between the tested sugar beet cultivars on both count days in each of the three experiments.

The analysis of mean values revealed the highest percentage of live seedlings (above 90\%) after the first water deficit for cv. Sokrates (93.6\%), Expert (92.3\%), and Lukas (90.1\%) (Tab. 4).

After the second simulated soil drought, the highest percentage of live seedlings (above 70\%) was noted in cv. Huzar (83.2\%), Lukas (73.2\%) and Expert (70.7\%) (Tab. 5). Expert, the only drought-tolerant cultivar in the analysed group, proved to be resistant to soil moisture deficit. Our results did not confirm the findings of Sigl et al. (2012) who reported that Heterodera schachtii-tolerant cultivars of sugar beet are more resistant to drought. In our study, the Heterodera schachtii-tolerant cultivar Julietta was highly sensitive to water deficit. 
Table 4. Share of alive plants after the first water deficit in 3 experiments (D1, D2 and D3)

\begin{tabular}{|c|c|c|c|c|c|}
\hline \multirow{3}{*}{$\begin{array}{c}\text { Sugar beet } \\
\text { cultivar }\end{array}$} & \multicolumn{5}{|c|}{ Share of alive plants $(\%)$} \\
\hline & \multicolumn{3}{|c|}{ Mean } & Mean & \multirow[t]{2}{*}{ SD } \\
\hline & D1 & D2 & D3 & for D1, D2 and D3 & \\
\hline Agent & $21.5^{\mathrm{jk}}$ & $33.9^{j k}$ & $51.0^{f}$ & $35.5^{\mathrm{ghi}}$ & 13.1 \\
\hline Balladyna & $90.7^{\mathrm{b}}$ & $59.2^{\mathrm{rt}}$ & $41.8^{\mathrm{gh}}$ & $63.9^{\text {cdef }}$ & 23.4 \\
\hline Britannia & $69.6^{\mathrm{d}}$ & $71.6^{\mathrm{cd}}$ & $88.4^{\mathrm{c}}$ & $76.5^{\mathrm{abc}}$ & 10.5 \\
\hline Casino & $29.3^{\mathrm{i}}$ & $54.8^{\operatorname{tg}}$ & $89.1^{\mathrm{bc}}$ & $57.7^{\mathrm{efg}}$ & 26.2 \\
\hline Delano & $20.3^{\mathrm{k}}$ & $29.3^{\mathrm{k}}$ & $42.2^{\mathrm{g}}$ & $30.6^{\mathrm{i}}$ & 9.6 \\
\hline Expert & $98.1^{\mathrm{a}}$ & $86.9^{\mathrm{a}}$ & $92.0^{\mathrm{bc}}$ & $92.3^{\mathrm{a}}$ & 5.0 \\
\hline Goldena & $88.3^{\mathrm{b}}$ & $82.6^{\mathrm{ab}}$ & $94.4^{\mathrm{ab}}$ & $88.4^{\mathrm{ab}}$ & 6.6 \\
\hline Huzar & $89.2^{\mathrm{b}}$ & $81.2^{\mathrm{ab}}$ & $91.8^{\mathrm{b}}$ & $87.4^{\mathrm{abc}}$ & 5.3 \\
\hline Imperial & $54.6^{\mathrm{f}}$ & $62.5^{\mathrm{e}}$ & $80.7^{\mathrm{d}}$ & $65.9^{\text {bcdef }}$ & 12.2 \\
\hline Jagoda & $77.8^{\mathrm{c}}$ & $77.8^{\mathrm{bc}}$ & $92.3^{\mathrm{bc}}$ & $82.6^{\mathrm{abcd}}$ & 7.6 \\
\hline Jagusia & $44.7^{\mathrm{g}}$ & $53.2^{\mathrm{tg}}$ & $71.9^{\mathrm{e}}$ & $56.6^{\mathrm{efgh}}$ & 12.3 \\
\hline Janosik & $37.9^{\mathrm{h}}$ & $33.8^{\mathrm{jk}}$ & $32.7^{\mathrm{h}}$ & $34.8^{\text {hi }}$ & 3.3 \\
\hline Janowa & $37.4^{\mathrm{h}}$ & $48.4^{\mathrm{gh}}$ & $92.5^{\mathrm{bc}}$ & $59.4^{\text {defg }}$ & 25.0 \\
\hline Jonas & $31.0^{\mathrm{i}}$ & $34.1^{\mathrm{jk}}$ & $41.4^{\mathrm{gh}}$ & $35.5^{\mathrm{ghi}}$ & 5.4 \\
\hline Julietta & $62.3^{\mathrm{e}}$ & $69.3^{\mathrm{d}}$ & $91.0^{\mathrm{bc}}$ & $74.2^{\mathrm{abcd}}$ & 13.4 \\
\hline Lukas & $88.5^{b}$ & $83.6^{\mathrm{ab}}$ & $98.1^{\mathrm{a}}$. & $90.1^{\mathrm{a}}$ & 6.7 \\
\hline Monza & $29.8^{i}$ & $30.8^{\mathrm{k}}$ & $36.4^{\text {hi }}$ & $32.3^{\mathrm{i}}$ & 3.6 \\
\hline Nancy & $22.5^{j}$ & $34.0^{\mathrm{jk}}$ & $50.7^{\mathrm{f}}$ & $35.7^{\text {ghi }}$ & 12.5 \\
\hline Nevenka & $27.7^{\mathrm{ij}}$ & $32.5^{\mathrm{jk}}$ & $41.6^{\mathrm{gh}}$ & $33.9^{\text {hi }}$ & 6.8 \\
\hline Pasja & $62.6^{\mathrm{e}}$ & $37.8^{\mathrm{ij}}$ & $18.1^{\mathrm{j}}$ & $39.5^{\mathrm{ghi}}$ & 19.5 \\
\hline Pewniak & $70.5^{\mathrm{d}}$ & $73.2^{\mathrm{cd}}$ & $91.6^{\mathrm{bc}}$ & $78.4^{\text {abcd }}$ & 10.4 \\
\hline Schubert & $57.8^{\mathrm{ef}}$ & $32.3^{\mathrm{jk}}$ & $10.9^{\mathrm{k}}$ & $33.7^{\mathrm{hi}}$ & 20.4 \\
\hline Silvetta & $42.6^{\mathrm{gh}}$ & $42.0^{\mathrm{h}}$ & $47.5^{f}$ & $44.0^{\text {fghi }}$ & 3.3 \\
\hline Sokrates & $100.0^{\mathrm{a}}$ & $87.6^{\mathrm{a}}$ & $93.1^{\mathrm{ab}}$ & $93.6^{\mathrm{a}}$ & 5.9 \\
\hline
\end{tabular}

D1, D2 and D3 - calculated for 9 replicates; SD - standard deviation; means within the same column followed by the same letter are not significantly different

In the control treatment, where sugar beets were grown under optimal soil moisture conditions, significant losses in plant density were not observed between the second count of emerged seedlings and the end of the experiment.

Our results indicate that the sugar beet cultivars differed considerably in their resistance to periodic water deficit.

Different responses of sugar beet genotypes to soil moisture deficit at the initial stage of plant growth were also reported by Kenter et al. (2006) and Bloch (2006), and in consecutive stages of plant development - by Ober et al. (2004). The progressive decrease in global water resources, climate change, and water deficit forecasts in many sugar beet production regions in Europe will require cultivars that are tolerant or at least less sensitive to drought stress. Further research is needed to identify the sources of drought resistance and to apply them in the breeding and development of new cultivars of sugar beet and other agricultural crops. 
Table 5. Share of alive plants after the second water deficit in 3 experiments (D1, D2 and D3)

\begin{tabular}{|c|c|c|c|c|c|}
\hline \multirow{3}{*}{ Sugar beet cultivar } & \multicolumn{5}{|c|}{ Share of alive plants (\%) } \\
\hline & \multicolumn{3}{|c|}{ Mean } & Mean & SD \\
\hline & D1 & D2 & D3 & \multicolumn{2}{|c|}{ for D1, D2 and D3 } \\
\hline Agent & $11.0^{\mathrm{jk}}$ & $19.9^{\mathrm{jk}}$ & $30.2^{1 j}$ & $20.4^{\mathrm{ghi}}$ & 8.4 \\
\hline Balladyna & $58.8^{\mathrm{c}}$ & $43.8^{\mathrm{f}}$ & $37.3^{\text {gh }}$ & $46.6^{\mathrm{de}}$ & 8.9 \\
\hline Britannia & $27.7^{\mathrm{g}}$ & $23.6^{i}$ & $21.4^{\mathrm{kl}}$ & $24.2^{\text {ghi }}$ & 4.8 \\
\hline Casino & $15.1^{\mathrm{j}}$ & $20.8^{\mathrm{j}}$ & $31.4^{\text {hi }}$ & $22.4^{\text {ghi }}$ & 7.9 \\
\hline Delano & $8.0^{1}$ & $11.5^{\mathrm{h}}$ & $15.9^{\mathrm{mn}}$ & $13.7^{\mathrm{i}}$ & 3.7 \\
\hline Expert & $59.4^{\mathrm{c}}$ & $66.1^{\mathrm{f}}$ & $86.7^{\mathrm{c}}$ & $70.7^{\mathrm{abc}}$ & 13.9 \\
\hline Goldena & $72.7^{\mathrm{b}}$ & $50.3^{\mathrm{e}}$ & $36.9^{\text {gh }}$ & $53.3^{\mathrm{cd}}$ & 16.2 \\
\hline Huzar & $87.9^{\mathrm{a}}$ & $78.2^{\mathrm{a}}$ & $83.5^{b}$ & $83.2^{\mathrm{a}}$ & 4.5 \\
\hline Imperial & $32.7^{\text {ef }}$ & $45.4^{\mathrm{f}}$ & $67.3^{c}$ & $48.5^{\mathrm{de}}$ & 15.3 \\
\hline Jagoda & $51.6^{\mathrm{d}}$ & $59.6^{\mathrm{c}}$ & $79.2^{\mathrm{b}}$ & $63.5^{\text {bcd }}$ & 12.7 \\
\hline Jagusia & $14.7^{\mathrm{jk}}$ & $18.2^{\mathrm{kl}}$ & $21.8^{\mathrm{kl}}$ & $18.2^{\mathrm{ghi}}$ & 3.2 \\
\hline Janosik & $19.8^{\text {hj }}$ & $16.5^{\mathrm{lm}}$ & $14.5^{\text {no }}$ & $16.9^{\mathrm{hi}}$ & 2.5 \\
\hline Janowa & $14.0^{\mathrm{jk}}$ & $33.1^{\mathrm{g}}$ & $59.9^{d}$ & $35.7^{\mathrm{ef}}$ & 20.0 \\
\hline Jonas & $11.8^{\mathrm{jkl}}$ & $11.8^{\mathrm{h}}$ & $12.0^{\text {ou }}$ & $11.8^{\mathrm{i}}$ & 1.5 \\
\hline Julietta & $14.4^{\mathrm{jk}}$ & $25.6^{\mathrm{hi}}$ & $39.5^{\operatorname{tg}}$ & $26.5^{\text {ghi }}$ & 11.0 \\
\hline Lukas & $59.7^{\mathrm{c}}$ & $68.3^{b}$ & $91.6^{\mathrm{a}}$ & $73.2^{\mathrm{ab}}$ & 14.4 \\
\hline Monza & $14.5^{\mathrm{jk}}$ & $15.2^{\mathrm{m}}$ & $16.3^{\mathrm{mno}}$ & $15.3^{\text {hi }}$ & 1.1 \\
\hline Nancy & $11.6^{\mathrm{jk}}$ & $17.7^{\mathrm{kl}}$ & $25.2^{\mathrm{jk}}$ & $18.2^{\text {ghi }}$ & 6.1 \\
\hline Nevenka & $10.5^{\mathrm{kl}}$ & $11.3^{\mathrm{h}}$ & $11.9^{\mathrm{ou}}$ & $11.2^{\mathrm{i}}$ & 0.9 \\
\hline Pasja & $35.8^{\mathrm{e}}$ & $24.6^{\mathrm{i}}$ & $16.6^{\mathrm{lmn}}$ & $25.7^{\text {ghi }}$ & 8.5 \\
\hline Pewniak & $20.0^{\mathrm{h}}$ & $27.9^{\mathrm{h}}$ & $42.5^{\mathrm{f}}$ & $30.1^{\text {fgh }}$ & 10.0 \\
\hline Schubert & $28.4^{\mathrm{fg}}$ & $16.9^{1 \mathrm{~m}}$ & $7.3^{\mathrm{u}}$ & $17.5^{\text {ghi }}$ & 9.2 \\
\hline Silvetta & $15.5^{\mathrm{ij}}$ & $16.1^{\mathrm{lm}}$ & $17.8^{\operatorname{lm}}$ & $16.5^{\text {hi }}$ & 1.5 \\
\hline Sokrates & $75.0^{\mathrm{b}}$ & $54.6^{\mathrm{d}}$ & $48.2^{\mathrm{e}}$ & $59.3^{\text {bcd }}$ & 12.6 \\
\hline
\end{tabular}

D1, D2 and D3 - calculated for 9 replicates; SD - standard deviation; means within the same column followed by the same letter are not significantly different

\section{CONCLUSIONS}

1. In the investigated group of sugar beet cultivars, high emergence capacity (96-98\%) was observed in cv. Agent, Julietta, Sokrates, Lukas and Expert.

2. The greatest differences in seedling emergence between the cultivars were noted during the first seedling count in the cotyledon stage.

3. The seedlings of conventional sugar beet cultivars Huzar (Normal type) and Lukas (Sugar type) and the drought-tolerant cultivar Expert (Sugar type) were characterised by the lowest sensitivity to soil moisture deficit, expressed by the highest percentage of seedlings that survived the simulated drought (above $70 \%$ ).

4. Among the conventional cultivars of sugar beet, there are cultivars with a lower susceptibility to drought which should, therefore, be preferred for cropping in conditions of water deficit.

5. Fast and uniform emergence as well as tolerance of sugar beet seedlings to spring drought are fundamental for achieving a high plant density and consequently a high storage root yield and sugar yield. 


\section{REFERENCES}

Abdollahian-Noghabi M., Froud-Williams R.J., 1998. Effect of moisture stress and re-watering on growth and dry matter partitioning in three cultivars of sugar beet. Aspects Appl. Biol., 52, 71-78.

Allen R.G., Pereire L.S., Raes D., Smith M., 1998. Guidelines for Computing Crop Water Requirements. Crop Evapotranspiration FAO Irrig Drain, No. 56, 300.

Bloch D., 2006. Physiological effects of drought stress in sugar beet - Yield development, technical quality, genotypic variation. Univ. Göttingen, Diss., 21/2006, 68.

Brown K.F., Messem A.B., Dunham R.J., Biscoe P.V., 1987. Effect of drought on growth and water use of sugar beet. J. Agric. Sci. (Camb.), 109, 421-435, doi:10.1017/S0021859600081636

Clover G.R.G., Smith H.G., Azam-Ali S.N., Jaggard K.W., 1999. The effects of drought on sugar beet growth in isolation and in combination with beet yellows virus infection. J. Agric. Sci. (Camb.), 133, 251-261, doi:10.1017/S0021859699007005

Dunham R., 1988. Irrigation of sugar beet: the main effects. Brit. Sug. Beet Rev., 56, 34-37.

Gunasekera D., Berkowitz G.A., 1993. Use of transgenic plants with ribulose-1,5-bisphosphate carboxylase oxygenase antisense DNA to evaluate the rate limitation of photosynthesis under waterstress. Plant Physiol., 103, 629-635, doi:10.1104/pp.103.2.629

GzikA., 1996. Accumulation of proline and pattern of alfa amino acids in sugar beet plants in response to osmotic, water and salt stress. Environ. Exp. Bot., 36, 29-37, doi:10.1016/0098-8472(95)00046-1

Hills F.J., Winter S.R., Henderson D.W., 1990. Sugar beet. In: Steward BA, Nielson DR (Eds.), Irrigation of Agriculture Crops. Madison, Wisconsin, USA, 795-810.

Kenter Ch., Hoffmann Ch., Märländer B., 2006. Effects of weather variables on sugar beet yield development (Beta vulgaris L.). E. J. Agron. 24, 62-69, doi:10.1016/j.eja.2005.05.001

Kevrešan S., Krstić B., Popović M., Kovačev L., Pajević S., Kandrač J., Malenčić, D., 1998. Biochemical changes in sugar beet lines in dependence on soil moisture. Biol. Plant, 40, 245-250, doi:10.1023/A:1001020720616

Kryszan Cz., 1986. Spatial distribution of water-deficient areas in Poland. Zesz. Probl. Post. Nauk. Rol., 268, 37-45 (in Polish).

Michalska-Klimczak B., Wyszyński Z., 2010. Sugar beet yielding in various agronomical and environmental conditions. Part I. Yield and quality of roots and recoverable sugar yield. Fragm. Agron., 27(1), 88-97 (in Polish).

Nowakowski M., 2013. Usefulness of white mustard and oil radish as mulch, fertilizer and phytosanitary protection factor in sugar beet cultivation. PBAI-NRI Monographs and Dissertations, 43, 150 (in Polish).

Ober E.S., Clark C.J.A., Jaggard K.W., Pidgeon J.D., 2004. Progress towards improving the drought tolerance of sugar beet. Sugar Industry, 129, 101-104.

Pidgeon J.D., Werker A.R., Jaggard K.W., Richter G.M., Lister D.H., Jones P.D., 2001. Climatic impact on the productivity of sugar beet (Beta vulgaris L.) in Europe, 1961-1995. Agric. Forest Meteorol., 109, 27-37, doi:10.1016/S0168-1923(01)00254-4

Pidgeon J.D., Ober E.S., Qi A., Clark C.J.A., Royal A., Jaggard K.W., 2006. Using multi-environment sugar beet variety trials to screen for drought tolerance. Field Crops Research, 95, 268-279, doi:10.1016/j.fcr.2005.04.010

Piszczek J., Kierzek R., Nowakowski M., Górski D., Miziniak W., Ulatowska A., Moliszewska E., Siódmiak J., Ledóchowski P., 2012. Integrated protection methods for sugar beets and fodder beets - a manual for agricultural consultants. Ed. Ior-Pib, J. Piszczek and M. Mrówczyński. Poznan, 123 (in Polish). 
Romano A., Sorgona A., Lupini A., Araniti F., Stevanato P., Cacco G., Abenavoli M.R., 2013. Morpho-physiological responses of sugar beet (Beta vulgaris L.) genotypes to drought stress. Acta Physiol. Plant., 35, 853-865, doi:10.1007/s11738-012-1129-1

Sadeghian S.Y., Fazli H., Mohammadian R., Taleghani D.F., Mesbah M., 2000. Genetic variation for drought stress in sugar beet. J. Sugar Beet Res., 37, 55-77, doi:10.5274/jsbr.37.3.55

Sadeghian S.Y., Khodaii H., 1998. Diallel cross analysis of seed germination traits in sugar beet. Euphytica., 103(2), 259-263, doi:10.1023/A:1018365609713

Sigl G., Bodner G., Grundler F., 2012. Are nematode tolerant varieties drought tolerant too? Proc. $73^{\text {rd }}$ IIRB Congress, 229-230.

Skonieczek P., Koc J., 2011. The role of retention reservoir in sodium migration from agricultural and afforested catchment areas. Ecological Chemistry and Engineering A, 18, 3, 435-443.

Tuğrul K.M., Buzluk S., Boyacioğlu A., 2012. Seed drilling distance applications in sugar beet cultivation. Afr. J. Agric. Res. 7(28), 4110-4117.

Winter S.R., 1980. Suitability of sugar beets for limited irrigation in a semi-arid climate. Agron. J., 72, 118-123, doi:10.2134/agronj1980.00021962007200010024x

Wu G.Q., Wang C.M., Su Y.Y., Zhang J.J., Feng R.J., Liang N., 2014. Assessment of drought tolerance in seedlings of sugar beet (Beta vulgaris L.) cultivars using inorganic and organic solutes accumulation criteria. Soil Science and Plant Nutrition, 60(4), 565-576, doi:10.1080/00380768 .2014 .921579

\title{
WRAŻLIWOŚĆ 24 ODMIAN BURAKA CUKROWEGO NA NIEDOBÓR WODY PODCZAS WSCHODÓW
}

\author{
Pawet Skonieczek ${ }^{1}$ Mirosław Nowakowski ${ }^{1}$, Jacek Piszczek ${ }^{2}$, \\ Łukasz Matyka ${ }^{1}$, Marcin Żurek ${ }^{1}$, Bogumit Rychcik ${ }^{3}$, Milena Kaźmierczak ${ }^{3}$ \\ ${ }^{1}$ Pracownia Hodowli Odpornościowej i Technologii Produkcji Roślin Korzeniowych \\ Instytut Hodowli i Aklimatyzacji Roślin - Państwowy Instytut Badawczy \\ Al. Powstańców Wielkopolskich 10, 85-090 Bydgoszcz \\ ${ }^{2}$ Terenowa Stacja Doświadczalna w Toruniu, Instytut Ochrony Roślin - Państwowy Instytut Badawczy, \\ ul. Pigwowa 16, 87-100 Toruń \\ ${ }^{3}$ Katedra Agroekosystemów, Uniwersytet Warmińsko-Mazurski w Olsztynie \\ Pl. Łódzki 3, 10-718 Olsztyn \\ e-mail: pawelsko@wp.pl
}

Streszczenie. Celem 3 doświadczeń przeprowadzonych w latach 2012 i 2013 była ocena wschodów i wrażliwości 24 odmian buraka cukrowego na okresowe niedobory wody w glebie. Nasiona zostały wysiane do wypełnionych glebą płową typową (65\% polowej pojemności wodnej) kontenerów: 60x40x15 cm, które wstawiono następnie do fitotronów. Przez 2 tygodnie do pierwszego liczenia siewek utrzymywano temperaturę $10^{\circ} \mathrm{C}$, a następnie podwyższono ją do $15^{\circ} \mathrm{C}$, aby symulować wzrost temperatury występujący w okresie wiosennym na polu. W trakcie pierwszego etapu badań policzono wschody buraka cukrowego po 14 i 21 dniach od siewu. Po kolejnych dwu tygodniach, w fazie dwu par liści, wstrzymano nawadnianie siewek przez okres 6 dni w celu określenia w 7. dniu ich wrażliwości na niedobór wilgoci w glebie. Przedstawiony cykl prac symulujący suszę został powtórzony i siewki nie były zasilane wodą przez kolejne 6 dni. Po tym okresie policzono 
siewki oraz obliczono ponownie udział siewek, które przetrwały okresowy deficyt wody w stosunku do liczby siewek ustalonej przed obu okresami suszy. W następstwie trzech doświadczeń wykonanych w kontrolowanych warunkach stwierdzono, że dużą dynamiką wschodów (po 14 dniach) odznaczały się odmiany Janosik, Julietta i Sylvetta, natomiast wysokimi ostatecznymi wschodami (po 21 dniach) charakteryzowały się odmiany Agent i Julietta. Wykazano, że odmiany buraka cukrowego Huzar, Lukas i Expert są najmniej wrażliwe na deficyt wilgoci w glebie i w związku z tym mogą być zalecane do uprawy w rejonach, gdzie rejestruje się często niedobory opadów w początkowym okresie wegetacji. Wśród konwencjonalnych odmian buraka cukrowego występują zatem odmiany o mniejszej wrażliwości na suszę, która stwarza coraz częściej problemy w regionach intensywnej produkcji roślin korzeniowych.

Słow a kluczowe: burak cukrowy, wschody, przeżycie siewek, symulowana susza 